\title{
PAMIĘĆ O POPRZEDNIKACH I KLÓTNIE Z KAPITUŁĄ, CZYLI O DZIAŁALNOŚCI BISKUPA MIKOŁAJA STEFANA PACA NA RZECZ SKARBCA KATEDRY WILEŃSKIEJ
}

\begin{abstract}
W artykule przedstawiono bardzo mało znany fragment dziejów katedry wileńskiej i jej skarbca, czyli okresu 1671-1684, kiedy na tronie biskupim zasiadał Mikołaj Stefan Pac. Były to rządy trudne, bo obarczone sporami $\mathrm{z}$ niechętną nominacji kapitułą, walką nominata o biskupią stolicę z Kazimierzem Pacem - krewnym i jednocześnie biskupem żmudzkim, a także odbudową Wilna i Wielkiego Księstwa Litewskiego po latach wojny i okupacji moskiewskiej.

Umacniając własną pozycję Mikołaj Stefan Pac odwoływał się do swoich wielkich poprzedników, kreując swoistą, bo duchową genealogię powiązaną z dziejami państwa i diecezji. Pamięć o biskupach wileńskich pielęgnował poprzez dbałość o przedmioty ze skarbca katedralnego oraz ich fundacje liturgiczne, a także przez różnorodne druki i towarzyszące im kompozycje graficzne. Przemyślana autokreacja wiązała się z potrzebą sakralnej legitymizacji.

Na tym tle przedstawiono indywidualny wkład Mikołaja Stefana Paca w wyposażenie katedralnego skarbca. Dokonano krytycznej analizy dotychczasowych opinii o jego wybitniejszej postawie w dziejach skarbca katedralnego i ciekawych fundacjach artystycznych.
\end{abstract}

Słowa kluczowe: Mikołaj Stefan Pac, diecezja wileńska, Pacowie, Wilno, Wielkie Księstwo Litewskie, fundacje artystyczne.

\section{MIKOŁAJ STEFAN PAC BISKUPEM WILEŃSKIM}

Kiedy 22 maja 1671 roku zmarł Aleksander Sapieha zawakowała najważniejsza stolica biskupia Wielkiego Księstwa Litewskiego i piąta w hierarchii krzeseł kościelnych senatu Rzeczypospolitej². Z woli króla Michała Korybuta Wiśniowieckiego już w czerwcu nominatem został Mikołaj Stefan Pac (1623-1684), dotychczasowy wojewoda trocki (od 1651)

\footnotetext{
${ }^{1}$ Dr hab. Anna Sylwia Czyż, Instytut Historii Sztuki, Uniwersytet Kardynała Stefana Wyszyńskiego w Warszawie; e-mail: aniaczyz@ poczta.onet.pl.

Anna Sylwia Czyż, DSc, PhD, Institute of Art History, Cardinal Stefan Wyszyński University in Warsaw; e-mail: aniaczyz@poczta.onet.pl.

${ }^{2}$ Prezentowany artykuł jest rozwinięciem wątków omówionych w trzecim rozdziale książki Fundacje artystyczne rodziny Paców: Stefana, Krzysztofa Zygmunta i Mikołaja Stefana. „Lilium bonae spei ab antiquitate consecratum”, Warszawa 2016.
} 
trzymający od kwietnia 1670 roku przywilej na prestiżową kasztelanię wileńską ${ }^{3}$, który zaledwie dwa lata wcześniej uzyskał od „miłej małżonki”4 Teodory Zofii z Tryznów (zm. po 1695 r.) akt zwalniający go z przysięgi małżeńskiej ${ }^{5}$, co z kolei pozwoliło mu 1 lipca 1670 roku przyjąć niższe święcenia kapłańskie ${ }^{6}$.

Decyzja króla podjęta w kontekście budowania w Wielkim Księstwie Litewskim przez starszego brata Mikołaja Stefana Paca - Krzysztofa Zygmunta (1621-1684) politycznego zaplecza dworu, a przede wszystkim hegemonii własnego rodu, spotkała się z umiarkowaną przychylnością kapituły, która co prawda od razu przyjęła nominata w poczet swoich członków, ale pełną akceptację uzależniała od zgody papieskiej przypominając, że kandydat powinien wcześniej przyjąć wyższe święcenia duchowne ${ }^{7}$ oraz uregulować status żony ${ }^{8}$.

3 Jeszcze w lipcu 1670 r. Mikołaj Stefan Pac podpisywał się jako kasztelan wileński. Archiwum Akt Dawnych w Warszawie (dalej jako AGAD) AR dz. V nr 11214/2 (Listy Mikołaja Stefana Paca), s. 101, 105, 107; Diariusz sejmu nadzwyczajnego 1670 roku, oprac. K. Przyboś, M. Ferenc, Kraków 2004, s. 101.

4 Tak zwracał się do żony w dokumencie majątkowym wystawionym w Wilnie 6 II 1651 r. Lietuvos valstybès istorijos archyvas w Wilnie (dalej jako LVIA) SA 7, k. 263-266v. Ślub Mikołaja Stefana Paca z Tryznianką odbył się w $1649 \mathrm{r}$. lub w pierwszej połowie następnego roku. AGAD Platerowie z Antuzowa, nr 8 (Prawo przedażne dóbr Dusiaty, 7 X 1650 r.), k. 21 - w dokumencie tym Pac po raz pierwszy przywołuje osobę żony. Data ślubu w Polskim stowniku biograficznym została określona na ok. 1650 r. A. Rachuba, Pac Mikołaj Stefan [w:] PSB, t. 24, Wrocław-Warszawa-KrakówGdańsk 1979, s. 741. Cytaty źródłowe (niepublikowane) oraz z literatury dziewiętnastowiecznej zostały opracowane zgodnie z zasadami transkrypcji źródeł historycznych (do poł. XVIII w.) i literackich typu $\mathrm{B}$ z pozostawieniem oboczności typowych dla melodii danego tekstu. Ujednolicono pisownię małych i wielkich liter, a uzupełnienia zaznaczono przez nawiasy kwadratowe. Wszelkie wtrącenia dodatkowo opisano.

${ }^{5}$ W dokumencie wystawionym 10 X 1669 r. Teodora Zofia z Tryznów napisała m.in. „,zważywszy świątobliwe do stanu duchownego przedsięwzięcie małżonka [...] w obecności Aleksandra Sapiehy, biskupa wileńskiego, na to przedsięwzięcie zezwala i małżonka swego od stanu i przysięgi małżeńskiej uwalnia. Jednocześnie zwraca małżonkowi swemu, za wypłaceniem summy według zapisu jej należnej, wszystkie prawa swe na starostwa mężowskie”. Cyt. za J. Wolff, Pacowie. Materyjaty historyczno-genealogiczne, Petersburg 1885, s. 178. Dokument pod datą 22 III 1670 r. został podany przez Mikołaja Stefana Paca do Metryki Litewskiej.

${ }^{6}$ Biografia Mikołaja Stefana Paca, także w kontekście jego działalności biskupiej, zob. A. Rachuba, op. cit., s. 738-741; A.S. Czyż, Fundacje..., s. 381-400 (tu starsza literatura i źródła archiwalne).

${ }^{7}$ Mikołaj Stefan Pac otrzymał w Rzymie w miesiącach styczeń - luty 1673 r. święcenia subdiakońskie, diakońskie i kapłańskie. 18 III 1673 r. papież mianował go referendarzem obojga sygnatur, 29 IV prałatem domowym, a $16 \mathrm{~V}$ protonotariuszem apostolskim. Klemens X obdarzył go także złotym krzyżem laterańskim. Magnat przeszedł wówczas krótki kurs seminaryjny połączony z rekolekcjami. „Co do teologii i nauk duchownych, pan wojewoda znał łacinę jak ksiądz, a dogmata wiary, ceremonie kościelne i Pismo Ś[więte], nawet jak jaki doktor akademii jezuickiej” (W. Przyagłowski Żywoty biskupów wileńskich, t. 3, Petersburg 1860, s. 29) pisał w dziewiętnastym stuleciu historyk diecezji wileńskiej, z którym należy się zgodzić przypominając, że Pac studiował filozofię najpierw w Wilnie, a na początku 1641 r. udał się na studia do Europy Zachodniej. Od wiosny do końca 1643 r. był studentem wydziału filozoficznego uniwersytetu w Inglostacie. J. Drews, Honor consummatus liliorum [...] Nicolai Stephani Pac [...] episcopi Vilnensis...., Wilno 1682, k. 1; M.J. Sapieha, Lilium praesulea tiara coronatum [...] in solenni inauguratione in antistitem Vilnensem [...] Nicolai Stephani Pac..., Varsavia 1682, k. 1, 9.

${ }^{8}$ Bardzo trudno prześledzić późniejsze losy Teodory Zofii z Tryznów. Dziewiętnastowieczni historycy uważali, że wstąpiła do klasztoru benedyktynek w Wilnie, jednak nie odnotowano jej w spisach zakonnic (np. M. Borkowska, Leksykon zakonnic polskich epoki przedrozbiorowej, t. 2 i 3, War- 
Tak rozpoczęła się trwająca aż 11 lat procedura znaczona sporami z kanonikami wileńskimi, które sięgały nie tylko Warszawy i Gniezna, ale również Rzymu, gdzie Mikołaj Stefan Pac w swojej sprawie wyjeżdżał trzy razy i gdzie na skargę zdążali także członkowie kapituły. Kłótnie rozpalała przede wszystkim kwestia dostępu nominata do bogatych dóbr biskupich oraz prawo do sprawowania władzy duchowej ${ }^{9}$, a podsycała wielokrotnie urażona duma obu stron konfliktu i specyficzna osobowość samego nominata charakteryzującego się niestałością i zapalczywością, drażniącego kapitułę sprawowaniem obrzędów zarezerwowanych na czas po konsekracji i noszeniem stroju biskupiego ${ }^{10}$ tak jak to widzimy na kopii portretu wykonanego w 1673 roku przez Daniela Schultza ${ }^{11}$, wiszącej niegdyś w zakrystii kościoła karmelitów bosych w Wilnie ${ }^{12}$.

szawa 2005 i 2008). W fakt ten powątpiewał Józef Wolff, ponieważ od lat 70. do 90. XVII w. jako „wojewodzina trocka” Tryznianka występowała w różnorodnych aktach majątkowych. Wiadomo, że za unieważnienie małżeństwa żądała rekompensaty finansowej w wysokości 13 tysięcy złotych, a formalnie śluby zakonne (zapewne z możliwością swobodnego poruszania się) złożyła dopiero 8 XII 1677 r., co ostatecznie otworzyło procedurę zatwierdzania na urzędzie Mikołaja Stefana Paca. Niestety nie wiadomo, do którego klasztoru wstąpiła. LVIA SA 9, k. 938-939v; J. Wolff, op. cit., s. 174, 178, 184-188; J. Kurczewski, Kościót zamkowy czyli katedra wileńska w jej dziejowym, liturgicznym, architektonicznym i ekonomicznym rozwoju, t. 1, Wilno 1908, s. 158; t. 3, Wilno 1916, s. 204; W. Przyagłowski, op. cit., t. 3, s. 28-29; K. Bobiatyński, Michat Kazimierz Pac wojewoda wileński, hetman wielki litewski. Działalność polityczno-wojskowa, Warszawa 2008, s. 244.

${ }^{9}$ Jeszcze 16 XI 1672 r. Mikołaj Stefan Pac został mianowany administratorem biskupstwa wileńskiego in temporalibus, a 11 VIII 1673 r. in spiritualibus, co jednak kapituła kwestionowała.

${ }^{10}$ W. Przyagłowski, op. cit., t. 3, s. 30, 36. Mikołaj Stefan Pac oporną kapitułę zwykł wyzywać od „osłów i cieląt”. Wincenty Przyagłowski opisywał go następująco: ,nominat wielkiego rodu i znaczenia, przytem bogacz milionowy, miał dumę niedostępną towarzyszkę tytułów i bogactw, której i zostawszy duchownym nie był w stanie pohamować. [...] Przy tem charakter miał skłonny do gniewu i popędliwy, za fraszkę gotów był sądzić i karać, równie jak za wielkie przestępstwo. A jako człowiek twardy i razem prawego serca, nie umiał ukrywać swoich myśli i uczuć, przeto w mowie był nieostrożnym” (ibidem, s. 34-35). Wtórował mu Jan Kurczewski: „będąc panem z rodu i dostojnikiem z zasług, z góry patrzał na swą przeciwniczkę i nie szczędził jej przymówisk, oraz uszczypliwych uwag w oczy i poza oczyma. Charakter jego szczery i otwarty nie liczył się z tem, co i o kim mówi: zdanie swoje wygłaszał jawnie i bez ogródek, sądami swymi dotknął mężów zasłużonych [...]. Sam więc rozdmuchiwał ogień, który go miał dotknąć”. J. Kurczewski, op. cit., t. 1, s. 160-161.

11 Львівська національна галерея мистецтв (nr inw. ж 4199, do 1940 r. w Muzeum Książąt Lubomirskich we Lwowie, płótno 100 x $77 \mathrm{~cm}$ ). Wzmiankowana kopia została ostatnio przypisana Johannowi Gotthardowi Berchhoffowi, malarzowi działającemu na terenie Wilna w latach 1676-1690. A.S. Czyż, Kościót świętych Piotra i Pawta na Antokolu w Wilnie, Wrocław-WarszawaKraków 2008, s. 173-174; M. Matušakaitè, Portretas lietuvos didžiojoje kunigaikštystëje, Vilnius 2010, s. 316; Lietuvos didžiosios kunigaikštystès valdu ir didiku portretami iš ukrainos muzieju [katalog wystawy], Lietuvos dailès muziejus Vilniaus paveikslų galerija, 4 VII - 28 X 2012, Vilnius 2012, s. 95, 286-289.

12 M. Matušakaite, op. cit., s. 339, 343 (łączy błędnie portret Mikołaja Stefana Paca z galerią wizerunków członków kapituły wileńskiej, datacja przed 1684 r.); Lietuvos..., s. 286-289 (tu datowanie portretu na ok. 1684 r., wizerunek połączono błędnie z galerią portretową biskupów wileńskich. O tym, że pierwotnie portret wisiał w zakrystii kościoła pw. św. Teresy, świadczą analogie kompozycyjne do pozostałych konterfektów Pacowskich z tej świątyni, wymiary oraz charakterystyczny błąd w wykonanym później podpisie odnotowanym w archiwaliach karmelitańskich). LVIA f. 694 ap 1 no 3670 (Akta wizytacji kościoła pw. św. Teresy w Wilnie, 1828 r.), k. 259v. 
Co gorsza do eskalacji niesnasek dążył biskup żmudzki Kazimierz Pac (zm. 1695) starając się storpedować kandydaturę kuzyna ze starszej tzw. kanclerskiej linii rodu na własną korzyść, nie wahając się podczas jego nieobecności zajmować pałace w Wilnie i w Werkach, a także urzędować w dobrach stołowych biskupstwa wileńskiego. Działo się to w momencie najgorszym z możliwych, kiedy to wraz ze wstąpieniem na tron Jana Sobieskiego Pacowie tracili pełnię władzy w Wielkim Księstwie Litewskim ${ }^{13}$.

Kresu wzajemnej niechęci nie przyniosła konsekracja Mikołaja Stefana Paca 25 maja 1682 roku $^{14}$. Niecałe dwa lata później, 8 maja jedyny z Paców na stolcu biskupstwa wileńskiego zmarł, a kapituła na wieść o jego śmierci wysłała dwóch kanoników do spisania pozostawionego przez niego majątku, mimo że zapisy testamentowe ominęły i kapitułę i katedrę ${ }^{15}$. W 1685 roku oficjalnie ze względu na długi kapituły oraz, jak uważano, niezbyt częste użytkowanie i koszty utrzymania postanowiono sprzedać pałac w Warszawie, który Mikołaj Stefan Pac wystawił przy ul. Długiej, a 17 czerwca 1683 roku przekazał swym następcom ${ }^{16}$. Była to jedna z realności, jakie zostawił biskupom wileńskim, by mieli „,dokąd przyjechać, nie tak jak ja, którym wszędy pustki znalazł"17.

Więcej na temat portretów Paców z kościoła karmelitów bosych w Wilnie zob. A.S. Czyż, Fundacje..., s. 15, 83, 186-189, 390-391.

${ }^{13}$ Biskupa żmudzkiego wspierał brat - hetman litewski i wojewoda wileński Michał Kazimierz (1624-1682), co prowadziło nie tylko do eskalacji konfliktu, ale i osłabienia fakcji pacowskiej, jako że obaj byli jej prominentnymi członkami. Przy tym Mikołaj Stefan Pac jako nominat występował przeciw hetmanowi litewskiemu również ze względu na lokowanie wojsk w dobrach biskupich i tolerowanie przez Michała Kazimierza Paca wyczynów żołnierzy, w tym zabójstwa plebana wobolnickiego. K. Bobiatyński, op. cit., s. 399-400.

${ }^{14}$ Ingres zorganizowano jeszcze tego samego roku 7 IX, kiedy to kapituła wraz z zakonnikami wileńskimi Mikołaja Stefana Paca ,wysokiemi i wyniosłymi honorami, applauzami, bramami, panegirykami [...] na wjeździe [...] na biskupstwo [...] przyjęli, ozdobili i uszanowali” (M. Wojniłowicz, Exultavit [...] Mikołajowi Stefanowi Pacowi [...] przy solennym dziękczynieniu Рanu Bogu za otrzymana w Rzymie expedycyia..., Wilno 1682, k. 3). Ingres uświetniło m.in. przedstawienie teatralne urządzone przez jezuitów na scenie wystawionej na rynku. M. B. Topolska, Spoteczeństwo i kultura w Wielkim Księstwie Litewskim od XV do XVIII wieku, Poznań-Zielona Góra 2002, s. 319 (błędnie podane imiona biskupa). Zob. także J. Kurczewski, op. cit., t. 1, s. 162, 165. Według Wincentego Przyagłowskiego ingres Mikołaj Stefan Pac odbył dopiero w maju 1683 r., a 18 czerwca zarządził wizytację katedry. W. Przyagłowski, op. cit., t. 3, s. 61. Datę wrześniową potwierdza katalog biskupów wileńskich autorstwa Piotra Wijuka Kojałowicza. Vilniaus universiteto biblioteka (dalej jako VUB) f. 32295, k. 59v.

15 Dokument sporządzony w Wilnie 14 III 1682 r. oblatowano 17 V 1684 r. w księgach grodzkich grodzieńskich. Zachował się oryginał i kopia testamentu pochodzące $\mathrm{z}$ archiwum katedry w Wilnie. Oryginał przechowuje Lietuvos dailès muziejus w Wilnie (dalej jako LDM) B-5 Ap-1 b-15. Rzetelny odpis z początku XX w. znajduje się w Lietuvos mokslų akademijos Vrublevskių biblioteka (dalej jako LMAVB) f. 318-2309. Oba egzemplarze zostały przez autorkę porównane, na tej podstawie stwierdzono ich zgodność. Testamentu nie odnotowano w Polskim słowniku biograficznym.

${ }^{16}$ LDM B-5 Ap-1 b-15, k. 4v; LVIA SA 25, k. 620-623v; Summaryjny wypis z protokołów aktów kapituty kathedralnej wileńskiej od r. 1501 do r. 1783 października 22, oprac. K. Bohusz [w:] Описаніе рукописнаго отдъленія Виленской публичной библіотеки..., вып. 1, Вильна 1895, s. 107-108; W. Przyagłowski, op. cit., t. 2, s. 61-62; J. Wolff, op. cit., s. 183; J. Kurczewski, t. 1, s. $165 ;$ t. 3 , s. 248.

17 LDM B-5 Ap-1 b-15, k. 7v. W lipcu 1676 r. Mikołaj Stefan Pac kupił dwór Borciany (pow. kowieński), a dwa lata później od spadkobierców biskupa Jerzego Tyszkiewicza za 6 tysięcy nabył majątek Czabiszki (pow. wileński). Prowadził także akcje osiedleńcze w dobrach stołowych, gdzie 
Biorąc pod uwagę dramaturgię konfliktu Mikołaja Stefana Paca z kapitułą oraz krótki zaledwie dwuletni okres rządów diecezją po konsekracji należałoby zapytać czy hierarcha dbał o dziedzictwo najstarszej w Wielkim Księstwie Litewskim katedry, a jeśli tak to w jaki sposób oraz czy wykorzystywał je do autokreacji. Pytania te w literaturze przedmiotu nie były dotychczas formułowane, choć w kontekście zawiłej ścieżki zatwierdzania na stolcu biskupim wydają się oczywiste. Ważną częścią owego dziedzictwa był katedralny skarbiec, a badacze tego tematu m.in. Vydas Dolinskas i Gitana Zujienè ${ }^{18}$, nie wdając się w szczegóły działalności Mikołaja Stefana Paca, do dziś powtarzają za Kacprem Niesieckim, że „katedrę swoją w złoto, srebro, apparat bogaty i splendor sprowadził; bractwo przy niej założył" ${ }^{19}$. Należy jednak zapytać, czy słusznie hierarcha uchodzi za hojniejszego z biskupów wileńskich XVII wieku, skoro on sam zżymał się, że do aktywności przymuszają go ,jakimsi aktem capituli" ${ }^{20}$.

\section{DZIEDZICTWO KATEDRY WILEŃSKIEJ I JEJ ROLA W AUTOKREACJI MIKOLAJA STEFANA PACA}

Z całą pewnością Mikołajowi Stefanowi Pacowi nie był obojętny stan katedry i jej skarbiec, o czym przekonują obszerne fragmenty testamentu, jaki spisał 14 marca 1682 roku, a więc tuż przed konsekracją, nie szczędząc przy okazji przykrych słów kapitule. Oskarżając kanoników o niechlujstwo i chciwość w kontekście, co należy podkreślić, swego pochówku planowanego w kościele karmelitów bosych pw. św. Teresy w Wilnie, który jako mauzoleum fundowali jego rodzice Stefan (1587-1640) i Anna Maria Ancilla z Rudominów Dusiackich (zm. 1643) ${ }^{21}$, pisał: ,apparata moje chciałem był do katedry zapisać, ale widząc straszny tam nierząd, który się dzieje, a poglądając, jako w niwecz aparat godn[ej]

zamieszkało „więcej od kilkuset” chłopów. Uwagę poświęcał także hodowlanej zwierzynie, a swojemu następcy pozostawił obory, które ,zamnożył”. LDM B-5 Ap-1 b-15, k. 4v, 7v; LMAVB f. 318-2309, k. 13v; LVIA SA 25, k. 620-623v (Wilno 17 VI 1683 r.); J. Wolff, op. cit., s. 181-183; J. Kurczewski, t. 3, s. 248.

${ }^{18} \mathrm{~Np}$. Lietuvos sakraline daile XI-XX a. pradžia. Lietuvos tūkstantmečio programos ir Jubilejiniu 2000 metu parodos krikščionybé Lietuvos mene katalogas [katalog wystawy], Lietuvos dailès muziejus, t. 4 kn. 1, Vilnius 2006, s. 235; G. Zujienè, Historia skarbca katedry wileńskiej (od założenia do dzisiaj) [w:] Skarbiec katedry wileńskiej. Zamek Królewski w Warszawie 2 lipca - 28 września 2008, Zamek Królewski na Wawelu 15 października 2008 - 15 stycznia 2009 [katalog wystawy], red. D. Nowacki, A. Saratowicz-Dudyńska, Warszawa 2008, s. 41.

${ }^{19}$ K. Niesiecki, Herbarz Polski, wyd. J. N. Bobrowicz, t. 7, Lipsk 1841, s. 230. Zob. także J. Drews, op. cit., k. 10.

${ }^{20}$ LDM B-5 Ap-1 b-15, k. 7. Zob. także J. Kurczewski, op. cit., t. 3, s. 214. Przywołany komentarz Mikołaja Stefana Paca dotyczy sięgającego na Litwie 1 ćw. XVI wieku zwyczaju przekazywania po ingresie do skarbca katedralnego kielicha lub odpowiedniej sumy pieniędzy. Ofiarę tę przyrównywano niekiedy do posagu, który biskup wnosił swojej oblubienicy - Kościołowi wileńskiemu. W 1524 roku Jan z książąt litewskich ofiarował katedrze zamiast kielicha 100 złotych dukatów, które przeznaczono na remont dzwonnicy i katedry. W 1601 roju kielich i patenę ofiarował biskup Benedykt Wojna. W 1668 roku Aleksander Sapieha zobowiązał się podarować złoty kielich i patenę za 200 złotych. Zdarzało się, że nie przekazywano kielicha albo robiono to w kilka lat po ingresie lub poprzez zapis w testamencie. Zwyczaj zignorowali m.in. Abraham Wojna i Jakub Massalski. G. Zujienè, Ceremoniat ingresu biskupów wileńskich w XVII-XVIII wieku, ,Barok. Historia-Literatura-Sztuka", 13, 2006, nr 1 s. 72; eadem, Historia skarbca..., s. 36.

${ }^{21} \mathrm{Na}$ ten temat zob. A. S. Czyż, Fundacje..., s. 117-144. 
pam[ięci] (...) biskupa wileń[skiego] [Eustachego] Wołłowicza obrócili, który był perłami suto haftowany, perły wszytkie z niego wypruli, Pan Bóg to wie, gdzie się perły podziały, także infułę bogatą perłową popsowali, kamienie nie wiedzieć gdzie podziali22. Jam kazał naprawić i restaurować de novo, kamieni bogatych dwanaście do niej kupiwszy. Także monstrancję kamieniami sadzoną nieboszczyka ks[ię]dza [Jerzego] Tyszkiewicza biskupa wileń[skiego] barzo bogatą w niwecz obrócili, krzyż diamentowy ${ }^{23}$, który na kilkanaście tysięcy szacowano oderwali byli, żeby (...) mógł kto na swój obrócić pożytek, jako to i z ołtarzów Wołłowiczowskich srebrnych auszpurskiej roboty barzo bogatej ${ }^{24}$, sztuki srebrne pooddzierali i na swój pożytek obrócili. A jam kazał restaurować i koszt na to ważyłem, żeby całą monstrancję restaurowano, szkodzie, a po prostu strasznej krzywdzie zabiegając. Do tego poglądając jako srebro kościołowi katedralnemu zaginęło per initiam tych, którym należało wiedzieć. A co większa widząc, jako są alienans niektóre fundationes w katedrze, drugie non adimplentur per summam licentiam niektórych et contemptum legum. Oto znieśli ołtarz, który stał in medio ecclesiae, S. Crucis, fundacji dawnej witoldowskiej, którą auxit naddziad mój ks[ią]żę [Paweł] [H]olszański biskup wileński, po tym ją Walerian [Protasewicz] biskup auxit, który ołtarz consulto restaurując kościół kazano znieść ${ }^{25}$, żeby obligatione dość nie czynić, a intratę na swój pożytek brać" 26 .

Mikołaj Stefan Pac skomentował także katedralne „fundacje jako to lada jako idą, tam też jest alienata fundatis stryja mego ks[ię]dza Mikołaja Paca biskupa żmujdzkiego, który on był fundował. Do drugiego ołtarza Krzyża Ś[więtego] od ks[ię]dza [Mikołaja] Korzenieckiego fundowanego, a od stryja mego pomnożonego ${ }^{27} \mathrm{i}$ wiele innych fundacji, które całe jedne poginęli. (...) Zaczym taki nierząd widząc w tym kościele, jako gorszy nigdy być nie może, nic do niego nie zapisuję, boby i to wszytko privati potracili" 28 .

Utyskując nominat pisał dalej: ,jako Wołłowiczowska kaplica pustkami stoi (...), która ruinam patitur, nie pomniąc na to, co dziad ich [tj. biskup Eustachy Wołłowicz - A.S. Cz.] na tej kaplicy napisał: Violator operis, infelix esto. Któż tę kaplicę violat! Moskwa całą zostawili, ci ją violant, którzy dobra trzymają, a o kaplicę domu swego nie dbają [...]. Także

${ }^{22}$ Zob. G. Zujiené, Historia skarbca..., s. 36 i 40, gdzie wśród przedmiotów ofiarowanych przez biskupa Eustachego Wołłowicza autorka wymieniła: pastorał, złoty krzyż pektoralny wysadzany diamentami z łańcuchem, mitrę i pięć srebrnych świeczników.

${ }^{23}$ Zob. ibidem, s. 36, gdzie wskazane są następujące dary biskupa Jerzego Tyszkiewicza: złoty kielich ingresowy, złoty krzyż i kadzielnica, złota monstrancja zdobiona emalią i szlachetnymi kamieniami. Zob. także Skarbiec..., s. 150-152.

${ }^{24} \mathrm{Na}$ fragment ten powołuje się Piotr Jamski w artykule Ottarz relikwiarzowy w wileńskiej kaplicy św. Kazimierza w pierwszej połowie XVII wieku, „Barok. Historia-Literatura-Sztuka” 12, 2005, nr 2, s. 52, błędnie odczytując wyraz „ołtarze” jako „obrazy”, a łącząc je z wystrojem kaplicy Jagiellona sugeruje, że chodzi tu ewentualnie o tabliczki z historią życia św. Kazimierza, jakie były umieszczone na trumnie-relikwiarzu.

${ }^{25}$ Kopista testamentu z początku XX w. na marginesie zapisał, że ołtarz spalił się w 1610 r. (LMAVB f. 318-2309, k. 14v). Odnowiony ołtarz został zniszczony podczas okupacji Wilna przez wojska moskiewskie. Zob. także W. Zahorski, Katedra wileńska, Wilno 1904, s. 16-18.

${ }^{26}$ LDM B-5 Ap-1 b-15, k. 6v. Zob. także W. Zahorski, op. cit., s. 38-40, 83.

27 Ze spisu „Fundationes quorundam Altarium cum suis obligationibus” wynika, że biskup żmudzki Mikołaj Pac uczynił fundację na ołtarz w kaplicy Jasińskich, a proboszcz niemęczyński Mikołaj Korzeniowski na inny ołtarz w katedrze. VUB f. 4-A 2472 (Inwentarz katedry w Wilnie, 1598-1626), s. 90, 92.

${ }^{28}$ LDM B-5 Ap-1 b-15, k. 6v-7. 
kaplica Wojnowska pustkami stoi, żadnego ks[ię]dza nie mając. Ks[ią]dz Rappe nieboszczyk nie chował i teraz nie chowają, a piętnaście tysięcy ma intraty. Nuż insze kaplice: [K]ieżga[j]łowska, Jasińskich, Gasztołdowska, Pacowska nasza ${ }^{29}$, św. Kazimierza, niemal pustkami stoją, teraz dla wstydu jeszcze piątkowe trzymają nabożeństwo i to nie wiem jak długo będzie trwało, gdy proboszczowie i altaristowie suum quaestum non gloriam Dei quaerunt" 30 .

Abstrahując od niezwykle negatywnej i zapewne zbyt surowej oceny kapituły w kontekście dbałości o fundacje liturgiczne i opiekę nad skarbcem katedralnym ${ }^{31}$, pomijającej nie tak dawną pięcioletnią okupację moskiewską ${ }^{32}$, warto zwrócić uwagę przede wszystkim na dwie kwestie: przywołanie cennych przedmiotów sprawionych przez Eustachego Wołłowicza i Jerzego Tyszkiewicza oraz odwołanie do tradycji ołtarza Świętego Krzyża, które to retabulum - jak uważano w XVII wieku - powstało w czasach księcia Witolda, a następnie było otaczane opieką przez Pawła Holszańskiego i Waleriana Protasewicza ${ }^{33}$.

Oprócz podniesienia przez Mikołaja Stefana Paca kwestii wartości finansowej oraz wyakcentowanie własnego - kosztownego udziału w naprawie cennych przedmiotów ze skarbca katedralnego wypowiedź tę należy interpretować również w kontekście zainteresowania przeszłością i przemyślanego odwołania do dziedzictwa wielkich poprzedników, o które należy dbać także w wymiarze materialnym. Pozwalało to kreować własny wizerunek Mikołaja Stefana Paca jako ich godnego następcy, wpisując się w sakralną legitymizację trzymanej godności. Szczególnie ważne i nieprzypadkowe jest wyeksponowanie hierarchów, z którymi był spokrewniony, a więc Eustachego Wołłowicza (brat jego babki macierzystej) i Pawła Holszańskiego (brat jego prababki ojczystej), a także wspomnienie biskupa żmudzkiego Mikołaja (1570-1624) z tzw. hetmańskiej linii rodu Paców, jednego z opiekunów jego ojca Stefana.

Pierwsze miejsce w przywołanych fragmentach testamentu bez wątpienia zajmuje wybitna postać Eustachego Wołłowicza, o którym pamięć w drugiej połowie XVII wieku była nadal żywa. Postrzegano go jako biskupa nie tylko zaangażowanego w odnowę Kościoła, podobnie zresztą jak inni wspomniani przez Mikołaja Stefana Paca kapłani - Paweł Holszański, Walerian Protasewicz, Jerzy Tyszkiewicz i Mikołaj Pac, ale także jako tego, który swą stolicę ubogacił wspaniałymi fundacjami. Zaliczyć do nich należy przykatedralną grobową kaplicę Najświętszej Maryi Panny, ale także modernizację pałacu biskupiego i wystawienie rezydencji w Werkach, którą tak chętnie zajmował biskup żmudzki Kazimierz

${ }^{29}$ Być może chodzi o kaplicę św. Ignacego, gdzie znajdowała się płyta nagrobna Zofii z Wiśniowieckich Pacowej (1568-1619), fundowana przez jej syna Aleksandra (zm. po 1635). W. Zahorski, op. cit., s. 109; A.S. Czyż, Pacowska pompa funebris - pamięć o zmartych jako element propagandy rodu [w:] Nie wszystek umrę. Pamięć o zmartych w kulturze staropolskiej, red. A. Jankowski, A. Klonder, Bydgoszcz 2015, s. 110.

${ }^{30}$ LDM B-5 Ap-1 b-15, k. 7.

${ }^{31}$ Mikołaj Stefan Pac tłumaczył, że opisuje stan katedry ze względu na swego następcę. Z kolei kopista testamentu z początku XX w. na marginesie zapisał, by ostre słowa biskupa rozważyć w kontekście jego sporów z kapitułą wileńską. Przy tym uznał je za przesadzone, a stan skarbca wiązał z okupacją moskiewską. LMAVB f. 318-2309, k. 14v.

${ }_{32}$ Zob. G. Zujienè, Historia skarbca..., s. 39-40.

${ }^{33}$ Obecnie uważa się raczej, że ołtarz fundacji Witolda i ołtarz Świętego Krzyża fundacji Waleriana Protasewicza były dwiema oddzielnymi inicjatywami religijno-artystycznymi w katedrze wileńskiej. Nie można wykluczyć, że ołtarz Witolda znajdował się w kaplicy Świętego Krzyża, a identyczne wezwanie prowadziło do późniejszych konfuzji. VUB f. 4-A 2472. 
Pac podczas nieobecności nominata wileńskiego. Nie zapominano również o udziale Eustachego Wołłowicza w powstaniu kaplicy św. Kazimierza ani o bogatych darach, jakie przekazał do katedry ${ }^{34}$.

O ile wspomnienie wybitnych biskupów wileńskich jest oczywiste i wiąże się ze swoistą genealogią ducha, a częściowo także krwi, o tyle oryginalnie prezentuje się odwołanie do fundacji księcia Witolda, która miała być podtrzymywana przez „,naddziada” Mikołaja Stefana Paca - Pawła Holszańskiego i Waleriana Protasewicza a więc biskupów, którzy sprawowali swoją posługę za rządów ostatnich Jagiellonów. Było to wyraźne podkreślenie najdawniejszych dziejów katedry wileńskiej z czasów zaprowadzania chrześcijaństwa i jego utwierdzania w dobie reformacji postrzeganej jako nowa epoka pogańska oraz podkreślenie pierwszeństwa katedry w Wielkim Księstwie Litewskim wraz z obowiązkiem podtrzymywania prestiżowych fundacji również w kontekście dbania o najstarsze - przykatedralne kaplice wzniesione przez Gasztołdów, Jasińskich i Kieżgajłów. Nieprzypadkowo w zestawieniu tym pojawiła się również kaplica św. Kazimierza wznoszona przez przedstawicieli panującej i spokrewnionej z Jagiellonami dynastii, która z kolei związana była z fundacją ołtarza Świętego Krzyża ${ }^{35}$.

Wyraźnie obecna w przytoczonym fragmencie testamentu wiedza na temat dziejów katedry i wrażliwość historyczna biskupa wileńskiego nie powinna dziwić, bowiem jako absolwent szkół jezuickich wyniósł z nich m.in. zainteresowanie dziejami powszechnymi i indywidualnymi. Był także pierwszym, który rozpoczął sumienne studia nad genealogią własnej rodziny wykazując się samodzielnym osądem faktów ${ }^{36}$, śmiało zaprzeczając ugruntowanej w Europie tezie o rzymskim pochodzeniu Gozdawitów i pokrewieństwie Paców z de'Pazzimi. Odwołując się do autochtoniczności rodu osadzał go wśród najstarszych: Kieżgajłów i Gasztołdów, którzy mieli własne kaplice przy pierwszej katedrze Wielkiego Księstwa Litewskiego ${ }^{37}$. Mikołaja Stefana Paca należy więc postrzegać jako osobę o wyrobionej świadomości historycznej, umiejętnie sytuującej najstarsze dzieje powierzonej sobie diecezji i jej katedry w kontekście historii państwa i jego władców, ale też sprawnie łączącego przeszłość z teraźniejszością ${ }^{38}$. Przy tym po koncept kontynuacji

${ }^{34}$ Zob. M. Kałamajska-Saeed, Litewska Pietà Michała Anioła [w:] Mowa i moc obrazów. Prace dedykowane profesor Marii Poprzęckiej, Warszawa 2005, s. 55-58; M. Janicki, Willa Eustachego Wottowicza w Werkach pod Wilnem i jej epigraficzny program ideowy, „Barok. Historia-Literatura-Sztuka”, 6, 1997, nr 2, s. 123-149. Na marginesie dodajmy, że aktywność na niwie fundacji artystycznych wileńskiego hierarchy nadal czeka na swojego badacza.

${ }^{35}$ Zdając sobie sprawę z potrzeby szczególnego honorowania świętego królewicza Mikołaj Stefan Pac opłacał muzyków przy kaplicy Jagiellona, a ponadto w 1673 r. deklarował większe uposażenie muzyki katedralnej. W. Przyagłowski, op. cit., t. 3, s. 29, 32; J. Kurczewski, op. cit., t. 1, s. 159, 165.

${ }^{36}$ Genealogia autorstwa Mikołaja Stefana Paca znana jest wyłącznie z jednej kopii, przechowywanej w zbiorach Biblioteki Czartoryskich (BCzart 425). Więcej na ta ten temat A.S. Czyż, Fundacje..., s. 404-409.

${ }^{37}$ Ibidem, s. 57-58, 64-65, 408-409. Mimo to Mikołaj Stefan Pac w panegirykach powstałych na okoliczność konsekracji biskupiej, ale także w działaniach związanych z propagowaniem kultu św. Marii Magdaleny de'Pazzi chętnie przystawał na wykorzystywanie legendy rodu spokrewnionego z florenckimi notablami oraz propagował kult karmelitanki. Ibidem, s. 412-414.

${ }^{38} \mathrm{O}$ świadomości historycznej i jej roli w autokreacji na początku epoki nowożytnej zob. Gryglewski 2012, s. 131-138, 243-248. 
chętnie sięgali pacowscy panegiryści wpisując się w nurt zaproponowany przez samego nominata ${ }^{39}$.

Nie można wykluczyć, że wyraźne podkreślenie dawności biskupstwa wileńskiego, a więc jego pierwszeństwa w Wielkim Księstwie Litewskim, było sprzeciwem wobec pretensji wysuwanych przez biskupa żmudzkiego Kazimierza Paca. Konsekwentnie swój prymat nad tzw. hetmańską linią rodu Mikołaj Stefan Pac zaznaczał jeszcze jako wojewoda trocki stosując w tytulaturze określenie „hrabia z Różanki (...), na Choroszczy pan i dziedzic" ${ }^{40}$ przypisując sobie prawo do dziedzictwa założyciela młodszej linii - Pawła Paca (zm. 1595), w którego rękach po Chodkiewiczach znalazła się Choroszcz ${ }^{41}$.

Zainteresowanie dziejami rodziny w kontekście poszukiwań własnego w niej miejsca jak też legitymizacja godności biskupiej przez opiekę nad dziedzictwem poprzedników zaowocowało grafikami z wizerunkami herbów złożonych Mikołaja Stefana Paca. Szczególnie ciekawy jest miedzioryt zamieszczony w liście pasterskim, jaki w 1682 roku tuż przed swą konsekracją skierował do duchowieństwa diecezji wileńskiej ${ }^{42}$, oraz ten dodany do wydanego kilka miesięcy później panegiryku pióra Jana Drewsa ${ }^{43}$. Choć ryciny w obu publikacjach ukazują analogicznie zakomponowane herby z ujmującymi je inicjałami identyfikującymi biskupa wileńskiego ${ }^{44}$, to dekorację obramienia potraktowano oddzielnie, akcentując inne aspekty jego godności. Ich dopełnieniem są epigramaty współtworzące słowno-wizualne stemmaty o przekazie skierowanym do duchownych, jak i świeckich odbiorców.

Dwupolowa tarcza serdeczna w słup prezentuje Gozdawę i Trąby (odmiana Rudomina) - a więc znak Paców i Rudominów Dusiackich. W kolejnych polach umieszczono herby Lis (pole 3) i Bogoria (pole 4) wskazujące na babkę ojczystą Agatę (Zofię) z Sapiehów i na babkę macierzystą Felicjannę Zofię z Wołłowiczów. Dalej znalazł się znak Odrowąż (pole 5) prababki ojczystej Maryny z Kapustów. Natomiast w polu 6 zamiast herbu Kroje Anny

39 Jezuici przypominali podczas ingresu Mikołaja Stefana Paca, że Akademię Wileńską wspierali jego poprzednicy, w tym przywołany w testamencie Walerian Protasewicz, który założył kolegium w Wilnie przekształcone następnie przez Stefana Batorego w uniwersytet. J. Drews, op. cit., k. 6v. Warto przypomnieć, że Mikołaj Stefan Pac wspierał szkolnictwo jezuickie, szczególnie w Wilnie. Finansował druk ksiąg o treściach religijnych, powstałych w kręgu jezuitów (np. K. Wijuk Kojałowicz, Kazania o męce Pańskiej [...] w kościele wileńskim ś[w]. Jana [...] na wielki piątek miane..., Wilno 1675), ale i stricte naukowych w tym z zakresu medycyny (np. W. Tylkowski, Disquisitio physica ostenti duorum puerorum..., Oliva 1674). VUB f. 3-2237 (Mowa ku czci Mikołaja Stefana Paca), k. 81; J. Drews, op. cit., k. 6v.

${ }^{40}$ LMAVB f. 264-1362 (List Mikołaja Stefana Paca w sprawie cerkwi w Choroszczy, Choroszcz 28 III 1669 r.), k. 1. W tytulaturze Mikołaj Stefan Pac wymieniał także, prócz województwa trockiego, starostwa które trzymał: krzyczewskie, ołuczyckie, skierstymońskie.

${ }^{41} \mathrm{O}$ ile dobra różańskie pozostały w rękach wnuków Pawła Paca, o tyle właścicielem Choroszczy stał się ojciec Mikołaja Stefana Paca, po którym dziedziczył. A.S. Czyż, Fundacje..., s. 36, 61, $100-101$.

${ }^{42}$ Modus et ordo boni regiminis in dioecesim Vilnensem introducendi sancitus et ex mandato [...] Nicolai Stephani Pac..., Vilnae 1682, k. 1v. Egzemplarze starodruku z ryciną znajdują się w VUB (sygn. III 10792), w klocku przechowywanym w LMAVB (sygn. L-17/145/1-2) oraz w bibliotece PAU w Krakowie (sygn. Cim 2420).

43 J. Drews, op. cit., k. 1v. Egzemplarze starodruku z ryciną znajdują się w BN w Warszawie (sygn. XVII.4.3056; XVII.4.290) oraz w VUB (sygn. III 18 136; sygn. III 10 909).

44 „N. S. P. / D. G. / E. V.” - skrót należy rozwinąć: Nicolai Stephani Pac Dei Gratia Episcopi Vilnensis. 
Rainy z Kopciów umieszczono Trąby. Na osi kompozycji herbowej, ale powyżej korony rangowej znajdującej się ponad tarczą serdeczną znalazł się hierogram Maryi w promienistej glorii ${ }^{45}$.

Biskup wileński przez konstrukcję herbu złożonego ukazał genealogię rodziny, podkreślając jej dawność i rozległe powiązania, a także określił własne miejsce w hierarchii rodu i usprawiedliwiał posiadane prerogatywy wobec diecezji wileńskiej. Poprzez obecność Bogorii przypominał bowiem Eustachego Wołłowicza, z którym był spokrewniony przez matkę Annę Marię Ancillę z Rudominów Dusiackich. Taki zamiar potwierdzają słowa z panegiryku Jana Drewsa, który posługując się parafrazą Psalmu 92 jasno wyłożył powiązania Paca ze słynnym poprzednikiem, po którym ,scheda[m] thronum episcopalem versus porrectam ostentat hoc regii vatis oraculo inaratam: Parata sedes tua ex tunc" ${ }^{\prime 4}$. Co więcej na okoliczność nominacji biskupiej w rodzinie Paców pojawiła się legenda, jakoby tron wileński sam Eustachy Wołłowicz „gdy go (...) miał chrzcić, lubo insze imię rodzice na niego włożyć chcieli, przecież on go Mikołajem ochrzcił, i że miał siódmy[m, czyli siedemnastym - przyp. A.S Cz.] po nim biskupem być wileńskim" zapowiedział ${ }^{47}$.

Nie można więc wykluczyć, że herb Trąby nie tylko wskazywał na bardzo odległe parentele z Sudymontowiczami ${ }^{48}$, ale stanowił aluzję do biskupów wileńskich z rodziny Wojnów: Benedykta i Abrahama. Co prawda Pacowie tzw. linii kanclerskiej nie byli spokrewnieni z ich rodem, ale w tym konkretnym przypadku nie można wykluczyć chęci wskazania powinowactwa ducha i odwołania się do dziedzictwa poprzedników na tronie biskupim. Interpretacja taka jest o tyle możliwa, że o konieczności dbania o kaplicę Wojnowską apelował w testamencie Mikołaj Stefan Pac. Wiemy ponadto, że kształtowanie herbów złożonych odbywało się czasami z pominięciem zasad heraldyki, po to by wyeksponować ważne pokrewieństwo, czy też warstwę symboliczną związaną z każdym znakiem. Analiza herbów złożonych nie tylko więc pozwala na prześledzenie genealogii swego dysponenta, ale i odgadnięcie jego poglądów i aspiracji ${ }^{49}$.

Co ciekawe swój testament Mikołaj Stefan Pac opatrzył pieczęcią, na której odcisku herb złożony był prawidłowy, a wiec w polu 6 zamiast znaku Trąby znalazły się Kroje. Herb złożony zwieńczony został kapeluszem biskupim ujętym przez pastorał i miecz, wskazującymi na podwójną władzę biskupa na podległym mu terenie oraz jego zaangażowanie

${ }^{45}$ Herb złożony Mikołaja Stefana Paca znajduje się także na odcisku pieczęci wspomnianego wyżej dokumentu fundacyjnego cerkwi w Choroszczy (LMAVB f. 264-1362, k. 1). Niestety stan zachowania pozwala jedynie stwierdzić, że tarcza serdeczna została podzielona w słup. Tu zapewne znalazła się Gozdawa i Trąby (odmiana Rudomina). W polu 3 umieszczono herb Lis, w 4 Bogorię, a w 5 Odrowąż. Pole 6 uległo zatarciu.

46 J. Drews, op. cit., k. 17v. Zob. także M. J. Sapieha, op. cit., k. 6v, 10.

${ }^{47}$ K. Niesiecki, op. cit., s. 230. Zob. BCzart 425, s. 131.

${ }^{48}$ Raczej nie było to odwołanie do jeszcze odleglejszych parenteli z Radziwiłłami, z którymi łączyła Mikołaja Stefana Paca, wbrew polityce rodu, zażyła przyjaźń. Zob. także AGAD AR dz. II (Declaratia JM pana wojewody [trockiego] dana przez pana [Kazimierza Juliana] Puchalskiego JM panu kanclerzowi i JM panu hetmanowi WXL [Pacom], [1669 r.]), nlb.

49 Zob. podstawowy artykuł o tej tematyce: P. Stróżyk, O potrzebie i możliwościach badań nad herbami złożonymi. Uwagi na przykładzie ikonograficznych źródet heraldycznych z Wielkopolski [w:] Ad fonts. O naturze źródta historycznego, red. S. Rosik, P. Wiszewski, Wrocław 2004, s. 201-225. 
w sprawy Kościoła i ojczyzny ${ }^{50}$. To właśnie używanie przed konsekracją tego typu symboliki burzyła krew kanoników. Jednak moment spisywania testamentu przypadł na niecałe trzy miesiące przed uroczystościami konsekracji, jakie odbyły się w Warszawie pod przewodnictwem nuncjusza Opizia Pallaviciniego. Mikołaj Stefan Pac zwycięsko wychodził z bojów o wileńską stolicę i nie musiał udowadniać już swych praw.

Jak powiedziano wyżej, choć herb złożony w obu wydawnictwach z 1682 roku jest ten sam, to różne są obramienia. W liście pasterskim, skierowanym do duchownych diecezji wileńskiej Modus et ordo, jest to skromna rama akantowo-wolutowa, ponad którą umieszczono kapelusz biskupi z dwunastoma chwostami. Słowno-wizualna kompozycja składa się tutaj z lemmatu zaczerpniętego z Ewangelii św. Mateusza $(6,28)$ „Considerate lilia”, której rozwinięciem jest epigram:

„Splendida praesulei generis quot stemmata specto

Veri pastoris symbola tot numero.

Invitant ad prata tubae, dant Lilia pastum

Arcent infestos a grege tela lupos.

In super ordo anima est rerum, bonus inde probaris

Pastor, quando tuis das animam pro ovibus." 51

Autor konceptu - zapewne sam Mikołaj Stefan Pac ${ }^{52}$ - podkreślił więc swoją funkcję pasterza lokalnego Kościoła, który zgodnie z biblijnym wzorcem dba o powierzoną mu

50 W panegiryku Jan Drews powołuje się na słowa Jeremiasza (2 Mch 15, 16) „Accipe sanctum gladiu[m] munus a Deo, in quo deicies adversarios populi mei” pisząc "Quam virgam dicimus pastorale[m], virga est morigeris ovibus; at gladius anceps calcitra[n]tibus, lupisq[ue] irrumpentibus". J. Drews, op. cit., k. 17v. Zob. także utwór dedykowany Pacowi, w którym jest mowa o porzuceniu przez niego kasztelanii wileńskiej dzięki czemu stał się księciem i biskupem. VUB f. 3-2109 (Mowa ku czci Mikołaja Stefana Paca, po 1671 r.), k. 117v; J. Liškevičienè, Mundus emblematum: XVII a. Vilniaus spaudiniu ilustracijos, Vilnius 2005, s. 136-137; K. Bogacka, Insygnia biskupie w Polsce. Pierścien, pektorat, infuta XI-XVIII w., Warszawa 2008, s. 235-238; B. Czarski, Stemmaty $w$ staropolskich ksiażkach, czyli rzecz o poezji heraldycznej, Warszawa 2012, s. 35. Warto w miejscu tym przypomnieć słowa Gottfrieda Lengnicha: „powołanie biskupów nie tylko do rzeczy tyczących się wiary, ale też i do spraw Rz[ecz]p[ospo]l[i]tej się odnosiło". G. Lengnich, Prawo pospolite Królestwa Polskiego, Kraków 1836, s. 227. Gdański historyk i prawnik z XVIII w. podał także, że Szymon Starowolski błędnie napisał, ,jakoby wileński biskup [tj. Andrzej Jastrzębiec] tytułu księcia Iwana używał [...]. Za czasów Jana Kazimierza, Jerzy Biał[ł]ozor prymasem Litwy się nazwał, co gdy było z ujmą arcybiskupa gnieźnieńskiego, do zdania sprawy przed króla przywołany $[\ldots]$ wyznał, że bezprawnie tytułu prymasa Litwy użył i w imieniu swojem i swych następców ogłosił, iż [...] nigdy nadużywanym nie będzie". Ibidem, s. 246-247. Fakt ten jest przykładem dążenia do zrzucenia przez Kościół litewski gnieźnieńskiego zwierzchnictwa i politycznego separatyzmu litewskiego szczególnie intensywnego w 2 poł. XVII w. Mimo sprzeciwu arcybiskupa gnieźnieńskiego tytuł prymasa Wielkiego Księstwa Litewskiego w odniesieniu do biskupa wileńskiego nadal był używany. Stosowano go także wobec osoby Mikołaja Stefana Paca. M. Wojniłowicz, op. cit. k. 6v (tu także o posłudze biskupiej wobec króla i ojczyzny). Sam nominat w listach do Kosmy III Medyceusza podpisywał się jako „Prima Senatore e Principe di Lituania”. Np. Archivio di Stato di Firenze (dalej jako ASF) MP 4493 (List Mikołaja Stefana Paca do Kosmy III, Wilno 30 X 1677 r., Choroszcz 19 XI 1678 r.), k. 602v, 625.

${ }^{51}$ Modus..., k. 1v. W podobnym tonie jest utrzymany wiersz skierowany do Mikołaja Stefana Paca przez uczniów akademii wileńskiej powstały przed 1670 r. VUB f. 3-2237, k. 81-81v.

52 Na jego hipotetyczne autorstwo wskazuje charakter druku - list skierowany do kapłanów diecezji wileńskiej. Zbędnie przy tym przypominać, że umiejętność układania stemmatów, głoszenia panegiryków opartych na symbolice herbów nie była w siedemnastowiecznej Rzeczpospolitej niczym 
owczarnię. Poprzez swoje działania biskup stawał się przykładem dla innych, co ubrano w poetycką frazę, porównując go do strawy, jaką karmią się owce. Cnoty ugruntowane przez przodków reprezentowanych w herbie i przypomnianych w stemmacie poprzez symbole znaków (lilia, telum, tuba) zostały więc w nim spełnione.

Z kolei herb w powstałym na okoliczność ingresu panegiryku ujmuje bogata ornamentyka roślinna, wśród której dominuje akant, róże oraz kiście winnych gron. W dolnej części kompozycję podtrzymują dwa putta, a w górnej na osi znalazła się infuła z hierogramem IHS oraz, już pełnoprawnie, pastorał i miecz. Miedziorytowi towarzyszy epigram w formie dwóch dystychów elegijnych:

„Tela lupos ferient, agnos dum LILIA pascent:

At tuba PASTOREM ter canet (Io!) BONUM.

Omine non vano sic spondet, quae tibi, praesul,

Ceris in patriis VIRGO resedit apis" 53

Epigram poprzedza tytuł utworu, którego część (inicjały) została wpisana w kompozycję miedziorytniczą. Po rozwinięciu akronimu powstaje nadpis: „In stemma illustrissimi Nicolai Stephani Pac Dei gratia episcopi vilnensis", wskazujący adresata utworu ${ }^{54}$. Ponownie przedstawiono go jako dobrego pasterza uzbrojonego w cnoty przodków, nieprzypadkowo akcentując w epigramie słowa układające się w zdanie „Lilia pastorem bonum”, które połączono ze słowem „Virgo”. Oryginalność utworowi zapewnia sięgnięcie do wersów z Mądrości Syracha, w których opisano pszczołę o niepozornym wyglądzie, dającej jednak słodki „owoc miodu” ${ }^{55}$, co wskazuje na poświęcenie Mikołaja Stefana Paca i rozkwit Kościoła wileńskiego pod jego rządami. Skromność wyglądu połączona z wiarą w dziewiczą nieskazitelność pszczół, które, jak wierzono, są zapładniane dzięki ruchom warg, łączyła się od średniowiecza z symboliką maryjną ${ }^{56}$. Choć przywołanie pszczół wpisało się w bogatą owocowo-kwiatową ramę herbu to aluzje związane z Bogarodzicą wskazują przede wszystkim na ostatni element herbu złożonego biskupa wileńskiego - hierogram Maryi, który znajduje się w polu zakreślonym przez sześciopolową tarczę stając się integralną częścią nie tylko samego znaku, ale i przekazu ideowego ${ }^{57}$.

wyjątkowym. Po części był to wpływ nauczania jezuickiego, które odebrał także Mikołaj Stefan Pac, ale potrzeb i zainteresowania samej szlachty. Zob. B. Czarski, op. cit., s. 100.

53 J. Drews, op. cit., k. 1v. Na stronie tytułowej panegiryku litery nazwiska Pac zostały ujęte dekoracją akantową.

${ }^{54}$ Rozwinięcie za B. Czarski, op. cit., s. 132, gdzie także pierwsza - niepełna próba interpretacji stemmatu. Bartłomiej Czarski błędnie rozpoznał w herbie Odrowąż znak Ogończyk oraz nie zauważył symboliki maryjnej powiązanej z herbem i parafrazy z Mądrości Syracha w lemmacie. Ibidem, s. 131-133.

55 „Brevis in volatilibus est apis, et initium dulcoris habet fructus illius.” (Syr 11, 3). Łacińskie cytaty biblijne oparto na Wulgacie Klementyńskiej (Biblia sacra juxta Vulgatam Clementinum wyd. elektroniczne http://vulsearch.sourceforge.net/index.html) lub na Biblia sacra Vulgata, red. R. Weber, R. Gryson, Stuttgart 2007 (wyd. elektroniczne http://www.bibelwissenschaft.de).

${ }^{56}$ S. Kobielus, Bestiarium chrześcijańskie. Zwierzęta w symbolice i interpretacji. Starożytność i średniowiecze, Warszawa 2002, s. 266-267.

57 Tego że nie było to dziełem przypadku, dowodzi analogiczna kompozycja pieczęci pokojowej biskupa wileńskiego, gdzie w polu tarczy ponad Gozdawą znajdował się hierogram Maryi, a dopiero powyżej kapelusz z chwostami. Np. ASF MP 4493 (List Mikołaja Stefana Paca do Cosima Brunettiego, Wilno 20 XI 1677 r.), k. 517v; Archiwum Narodowe w Krakowie oddz. Wawel ZZG 754 (List Mikołaja Stefana Paca), k. 8. 
Pacowie przez skojarzenia nazwiska Pac z łacińskim słowem pax oraz lilii poświęconej Maryi z Gozdawą, nie tylko wołali do niej wraz z całym Kościołem Regina Pacis, ale postrzegali ją jako patronkę rodu ${ }^{58}$. Uważano, że Mikołaj Stefan Pac swój herb - lilię „miał ozdobioną imieniem" Matki Chrystusa ${ }^{59}$. Kult Bogarodzicy był więc nie tylko eksponowany w panegirykach dedykowanych Mikołajowi Stefanowi Pacowi, ale przekładał się na jego biskupią działalność, w dużej części wypływającą również z prywatnej, typowej dla Rzeczpospolitej drugiej połowy XVII wieku pobożności ${ }^{60}$. Szczególnie bliskie było mu arcybractwo Imienia Najświętszej Maryi Panny, które 8 marca 1671 roku zaprowadzono przy dawnej kaplicy Gasztołdów katedry wileńskiej ${ }^{61}$. Na jego funkcjonowanie nominat zapisał nie tylko sporą sumę, ale ostatecznie pochowano go w krypcie tej właśnie kaplicy ${ }^{62}$.

\section{FUNDACJE DO SKARBCA KATEDRY WILEŃSKIEJ}

Czas teraz zapytać co tak naprawdę Mikołaj Stefan Pac przekazał do skarbca katedralnego. Pewnym jest, że po powrocie z drugiej podróży do Rzymu nominat wileński ofiarował w 1673 roku niezachowany złoty kielich z pateną, na których odprawiał prymicję. W źródłach przedmiot opisano jako „ślicznej roboty”63, przy tym nie można wykluczyć, że

${ }^{58}$ Więcej na ten temat A.S. Czyż, Kościót..., s. 180-190. Zob. także J. Drews, op. cit., k. 10; M.J. Sapieha, op. cit., k. 11v-12.

${ }^{59}$ M. Wojniłowicz, op. cit., k. 8v.

${ }^{60}$ W testamencie Mikołaj Stefan Pac zwracał się do Maryi: „Matko Miłosierdzia prawda, żem twój był niegodny sługa, jednakże ile myśli mojej i sił we mnie było, zawszem chciał one na usługę twoją obrócić. Nie chciej że mnie w tej ostatniej godzinie mojej wespół z Najczystszym Oblubieńcem twoim Józefem ś[w]. opuścić. [...] Zawszem ja dufność swoją w łasce et pietate tua pokładał. Spraw mi odpuszczenie wszytkich grzechów moich [...] niech cię na wieki między chorami wysławiam anielskimi”. LDM B-5 Ap-1 b-15, k. 3v. Zob. także M. Wojniłowicz 1682, k. 9.

${ }^{61}$ Starania o zaprowadzenie arcybractwa rozpoczął sufragan białoruski Mikołaj Słupski, który udzielił niższych święceń kapłańskich Pacowi. Zgodę papieską wydano 3 X 1670 r. Podczas uroczystości wprowadzenia arcybractwa do księgi wpisali się najważniejsi hierarchowie i dygnitarze Wielkiego Księstwa Litewskiego, w tym pod numerem trzecim Mikołaj Stefan Pac, który już wówczas porzucił stan świecki. W późniejszym czasie do arcybractwa dołączyli Michał Korybut Wiśniowiecki i Eleonora. W. Przyagłowski, op. cit., t. 3, s. 28-29; W. Zahorski, op. cit., s. 117 (błędnie podaje, że bractwo wprowadzono 8 marca 1670 r.), 155-156; Skarbiec..., s. 160-161.

62 J.I. Kraszewski, Wilno od początków jego do roku 1750, t. 2, Wilno 1840, s. 223; K. Niesiecki, op. cit., s. 230. Chowając Mikołaja Stefana Paca w kaplicy Najświętszej Maryi Panny zmieniono zapis w testamencie hierarchy, który pragnął spocząć obok rodziców w kościele pw. św Teresy. Zmiany wprowadziła kapituła, powołując się, nie wiadomo czy prawdziwie, na wolę biskupa. Fundusz, który pierwotnie miał przypaść „Kalwarii Werkowskiej i już od tych złotych dwudziestu tysięcy, które należały do kościoła katedralnego, nie do katedry, ale dominikanom werkowskim płacić [...] co rok tysiąc cztyrysta złotych, a oni powinni co dzień za duszę moją dwie mszy ś[więte] odprawować”, przypadł ostatecznie kaplicy, ,którą zowią Gaudeamus” (LDM B-5 Ap-1 b-15, k. 4v). Zmiana ta musiała spotkać się z życzliwością dominikanów wileńskich, pozostających za sprawą biskupa w konflikcie z konwentem w Werkach. Zob. także LDM B-5 Ap-1 b-15, k. 4; LVIA SA 26 (Dokument kapituły wileńskiej, Wilno 11 VI 1684 r.), k. 123-124; A. S. Czyż, Fundacje..., s. 440-441.

${ }^{63}$ Summaryjny..., s. 105. Zob. także W. Przyagłowski, op. cit., t. 3, s. 29; J. Kurczewski, op. cit., t. 1 , s. 159,165 ; t. 3, s. 207; Skarbiec..., s. 164. 
rzymskiej (włoskiej). Dziewiętnastowieczni historycy diecezji wileńskiej podawali również, że do skarbca sprawił ornat ,srebrem naszywany w złote kwiaty, kielich srebrny całkiem wyzłacany i drogiemi kamieniami wysadzany, monstrancję srebrną wielką wyzłacaną, rzadkiej roboty, także chrzcielnicę bardzo piękną i kosztownej roboty. Prócz tego wiele innych apparatów, z drogiej materyi wyrabianych"64. Tymczasem w aktach kapituły z 26 maja 1683 roku odnotowano jedynie trzy pierwsze przedmioty: „ornat srebrem tkany, kielich i monstrancję, srebrne, złocone i sadzone drogiemi kamieniami”" ${ }^{\prime 65}$. Naczynia te pojawiły się w inwentarzu katedry z 1712 roku. Monstrancja była „srebrna pozłocista w promieniach sadzona kamieniami różnemi cum insignis Ch[ri]sti D[o]m[ini] Pacowska", a kielich „srebrno złocisty kamieniami sadzony Pacowski z patyną"66.

Wymienione przedmioty nie zachowały się do naszych czasów, a próby związania z Mikołajem Stefanem Pacem innych zabytków ze skarbca katedralnego okazały się nietrafione ${ }^{67}$. Do tej pory utrzymuje się natomiast opinia, że ufundował on luksusowy garnitur szat liturgicznych, reprezentowany obecnie przez ornat $\mathrm{i}$ dwie dalmatyki ${ }^{68}$ wykonane $\mathrm{z}$ włoskiego broszowanego jedwabiu (ok. 1620-1640) ze złotymi galonami ${ }^{69}$.

${ }^{64}$ W. Przyagłowski, op. cit., t. 3, s. 61.

65 J. Kurczewski, op. cit., t. 3, s. 246.

${ }^{66}$ LMAVB f. 43-19583 (Inwentarz katedry wileńskiej i kaplicy św. Kazimierza), k. 2v. Mikołaj Stefan Pac miał przy tym zastrzec, by darów nie przekazywano do innych kościołów nawet w charakterze depozytu. J. Kurczewski, op. cit., t. 1, s. 165; G. Zujienè, op. cit., s. 72.

${ }^{67}$ Skarbiec..., s. 169-173. Z Mikołajem Stefanem Pacem błędnie łączono m.in. imponującą monstrancję wykonaną w Augsburgu przez Wolfganga Caspara Kolba w latach 1691-1695 (Bažnytinio paveldo muziejus w Wilnie, $\mathrm{nr}$ inw. VA-112, wys. $69 \mathrm{~cm}$, stopa 23,80 x 19,20 cm), a więc co najmniej siedem lat po śmierci biskupa wileńskiego. Podobna uwaga dotyczy kielicha (Bažnytinio paveldo muziejus w Wilnie, nr inw. VA-33, wys. $29 \mathrm{~cm}$, średnica stopy $20,20 \mathrm{~cm}$ ), wykonanego w tym samym czasie i miejscu, ale w warsztacie Johanna Balthasara Sedle[t]zky'ego. Monstrancję i kielich Dariusz Nowacki, autor wnikliwych not w katalogu wystawy Skarbiec katedry wileńskiej, słusznie proponuje łączyć z biskupem żmudzkim Kazimierzem Pacem. Odnotować także należy srebrny pastorał przechowywany w Lietuvos dailès muziejus w Wilnie (nr inw. TD-1705 a, b, wys. $216 \mathrm{~cm}, 50 \mathrm{~cm}$ ) wykonany w technice kucia, repusowania, odlewania i grawerowania, który mógł sprawić albo Aleksander Sapieha, albo Mikołaj Stefan Pac. Brak przekazów archiwalnych oraz oznaczenia pastorału herbem uniemożliwia identyfikację fundatora. Rozpoznanie utrudnia także popularność zastosowanej formuły opartej na skręconej spiralnie wici akantu. Lietuvos..., s. 96, 256-257; B. R. Vitkauskiené, Złotnictwo wileńskie. Ludzie i dzieła XV-XVIII wieku, Warszawa 2006, s. 283, 303; Skarbiec..., s. 163.

${ }^{68}$ Garnitur w inwentarzu z 1712 r. opisano następująco: „ornat czerwony na dnie złocistym kwiaty suto złote, z herbem Pacowskim, z[e] stułą i manipularzem, kitajką zieloną podszyty. [...] Dalmatyk czerwonych na polu złotym kwiaty suto złote duże z[e] stułą jedną i manipularzami dwoma z herbami Pacowskiemi burtą pomarańczową podszyte.” LMAVB f. 43-19583, k. 6-6v. W inwentarzu z 1724 r. o dalmatykach napisano: ,,czerwone blaszkowe, kwiaty złote, wielkie, lite [...], na nich galony szerokie złote, w koło frędzelka złota podszyte płótnem żółtem, bez stuły i manipularza". LMAVB f. 43-19583, k. 22v.

${ }^{69}$ Garnitur przechowywany jest w Bažnytinio paveldo muziejus w Wilnie (nr inw. BT-1695/1-3, wymiary: ornat 123 x $74 \mathrm{~cm}$, dalmatyki 101,5 x 111,5 cm i 103,5 x $113 \mathrm{~cm}$, wysokość raportu tkaniny $36,5 \mathrm{~cm}$, szerokość galonu $3 \mathrm{~cm}$, na krawędziach 1,5 cm). Lietuvos..., t. 3, Vilnius 2004, s. 148; R. Pauliukevičiūtè, Šilkas ir auksas. XV-XVIII a. šilkiniai audiniai Bažnytinio paveldo muziejaus liturginiu drabužiu rinkinyje, Vilnius 2014, s. 43-45, 170. W obu katalogach tkanina datowana na 2 ćw. XVII w., a uszycie i wykończenie garnituru na 1675 r. Nowe, zaproponowane tu datowanie tkaniny tj. ok. 1620-ok. 1640 zostało określone na podstawie analogii do tkanin włoskich $\mathrm{z}$ tego 
Na ceglastoczerwonym tle tkaniny znajduje się motyw płaskich, rytmicznie i z dużym światłem zakomponowanych większego i dwóch mniejszych rzutów kwiatowych, wykonanych złotą nicią oplataną, przesuniętych względem siebie o pół szerokości raportu. Deseń należałoby określić jako wzór asymetrycznych gałązek kwiatowych w układzie rzędowym połączonych z motywem , a onde”. Szaty zostały uszyte w typowy sposób, a ich wyróżniającym się elementem jest jedynie rodzaj zastosowanego materiału o wyjątkowo dynamicznym wzorze, który powstał dzięki zaakcentowaniu układu diagonalnego tkaniny ${ }^{70}$. Funkcję kompozycyjną w wymienionych trzech szatach pełni także jedwabny galon, który wyznacza jednocześnie pola konstrukcyjne, współgrając kolorystycznie ze złotym deseniem.

Powodem związania z Mikołajem Stefanem Pacem opisanego zespołu szat ze skarbca katedry wileńskiej jest aplikowany herb wykonany w reliefowym hafcie na obu dalmatykach nićmi złotymi, srebrnymi i jedwabnymi na podkładach ${ }^{71}$. Niemniej warto zauważyć, że sam biskup wileński nie wspominał o darze. Analizowanego garnituru nie odnotowują akta kapituły, a jedynie wspominają o ornacie „srebrem tkanym”. Informacje o paramentach Mikołaja Stefana Paca z wyszywanymi złotymi kwiatami pojawiają się dopiero w dziewiętnastowiecznych opracowaniach ${ }^{72}$. W testamencie spisanym w 1683 roku biskup wileński wyraźnie zaznaczył: „apparata moje chciałem był do katedry zapisać, ale widząc straszny tam nierząd, który się dzieje" przekazał je do kościoła pw. św. Teresy ${ }^{73}$.

Herb biskupi umieszczony na dalmatykach $\mathrm{z}$ opisywanego kompletu pozbawiony jest inicjałów, a zatem równie dobrze można by go połączyć z biskupem żmudzkim Kazimierzem Pacem. Krewny Mikołaja Stefana nie tylko przyczyniał się do zaognienia konfliktu pomiędzy nominatem wileńskim a kapitułą, ale podejmował działania rezerwowane dla aktywności biskupa wobec własnej diecezji. Echem niespełnionych ambicji Kazimierza Paca związanych z biskupstwem wileńskim jest jego testament z 29 lipca 1694 roku, w którym nie tylko zadbał o wyposażenie katedry we Worniach, której był fundatorem, ale także katedry w Wilnie. Tej ostatniej ,,apparat (...) własny biskupi (...) kapy materjej bogatej atłasem czerwonym podszyty, dwie sztuki przy niej srebrne do zapinania in vim gratitudinis ku kathedrze wileńskiej zapisuję ${ }^{74}$. Przy tym ornat haftowany złotem, srebrem i jedwabiem

czasu np.: M. Taszycka, Wtoskie jedwabne tkaniny odzieżowe w Polsce w pierwszej połowie XVII wieku, Wrocław-Warszawa-Kraków-Gdańsk 1971, s. 59, il. 13-14, 22-23.

70 Tkaniny o takim deseniu cieszyły się w Rzeczpospolitej dużą popularnością. Wykonywano z nich nie tylko odzież, ale i szaty liturgiczne. Sprowadzano je przy tym z najważniejszych północnowłoskich warsztatów. Choć nie udało się odnaleźć analogicznej tkaniny, to odniesieniem dla niej są zabytki prezentowane m.in.: ibidem, s. 21, 24-25, 59-61, 63-66, il. 12-14, 23; R. Bonito Fanelli, Five Centuries of Italian Textiles. 1300-1800. A Selection from the Museo del Tessuto Prato, Firenze 1981, s. 238; L. Pesci, Il manifatture fiorentine del cinque e seicento nella collegiata di Montevarchi, ,Jaquard”, 2001-2002, nr 48, s. 2-6; D. Davanzo Poli, N. M. Riccadona, I. Panteghini, E. Masiero, M. Majcen, Otto secoli di arte tessile ai frari: sciamiti, velluti, damaschi, broccati, ricami, Padova 2014, s. 60-61.

${ }^{71}$ Pierwotnie herb znajdował się także na ornacie. Lietuvos..., t. 3, s. 148; R. Pauliukevičiūtè 2014, s. 43-45, 170.

${ }^{72}$ Np. W. Przyagłowski, op. cit., t. 3, s. 61.

${ }^{73}$ LDM B-5 Ap-1 b-15, k. 6v.

${ }^{74}$ W 1724 r. odnotowano opisano ją jako „biała dno złociste kwiaty srebrne ze złotem szczyt haftowany gęsto srebrem i wierzch takiż. Galony koło niej białe, szychowe, haftki srebrne duże par[a], wstęgi czerwone kwiatki na nich srebrne złociste, podszyta kapa kitajką pomarańczową, pod herbem Pacowskim". LMAVB f. 43-19583, k. 23. Zob. także LMAVB f. 43-19583, k. 8v. 
różnym z manipularzem i z stułą tejże materjej, oraz infułę na dnie srebrnym złotem szytą bogatą z fręzlą złotą atłasem ceglastym podszytą do tegoż kościoła oddaję"75. Choć opis szat nie dotyczy tych prezentowanych obecnie w wileńskim Bažnytinio paveldo muziejus to można założyć, że ornat i dwie dalmatyki zostały sprawione przez biskupa Kazimierza Paca, który przekazał je do katedry wileńskiej obok dwóch cennych wyrobów augsburskich - monstrancji i kielicha, które w starszej literaturze przedmiotu były błędnie łączone z osobą Mikołaja Stefana Paca ${ }^{76}$.

Z fundacji biskupa wileńskiego powstała natomiast puszka na komunikanty, którą Anna Saratowicz-Dudyńska i Dariusz Nowacki datują na lata 1671-168477. Wykonano ją w warsztacie wileńskim w technice złota kutego i ciętego, odlewanego. Na jej stopie znajdują się cztery owalne plakietki (emalia malarska), na których wyobrażono Matkę Boską z Dzieciątkiem Jezus, św. Mikołaja i św. Kazimierza, a także herb złożony fundatora ${ }^{78}$. Omawiany zabytek odznacza się wysokim poziomem wykonawstwa, a jego kształt można odnieść do produkcji warsztatów Prus Królewskich, gdzie tuż przed połową XVII wieku pojawiły się gładko opracowane kielichy. Jak zauważył Michał F. Woźniak, ich skromność jest pozorna, a doskonałe proporcje i efekty światłocieniowe stały się rozpoznawczym znakiem całej grupy. Analogią dla puszki ze skarbca wileńskiego mogą być kielichy wykonane przez Paula Detloffa (kościół pw. Świętej Trójcy w Działyniu, ok. 1665) czy Jakuba Beckhausena (kościół pw. św. Ignacego Loyoli w Gdańsku, ok. 1689-1699). Natomiast przykłady puszek całkowicie gładkich pochodzą dopiero z początku XVIII wieku (np. realizacje Jakuba Weintrauba) $)^{79}$.

W przypadku omawianej ,pyxis aurea Paciana" ${ }^{\circ 0}$ z wyważonymi proporcjami i elegancko ukształtowanym trzonem kontrastuje wyjątkowo niska jakość plakietek, ułomnie

${ }^{75}$ LMAVB f. 273-2425, k. 3v. Paramenty podarowane katedrze wileńskiej przez biskupa Kazimierza Paca odnotowano w inwentarzu z 1712 r.: ,ornat biały szyty złotem i srebrem Pacowski żmujdz[ki], z takąż stułą i manipularzem, pstrą materią podszyty” (LMAVB f. 43-19583, k. 5). Wymieniono także „dalmatyk staroświeckich pomarańczowych dwie z herbem Pacowskim, kitajką żółtą podszyte” z dodaną później notatką, że zostały ,przerobione”, dalej ,,dalmatyki Pacowskie drugie dwie czerwone $z$ herbami suto złote floresy atłasem cytrynowym podszyte” (w 1724 r. dopowiedziano, że były „,blaszkowe żółte z[e] srebrnemi kwiatkami gęstemi z herbem Pacowskim na nich korony szychowe i w koło kampanka białe podszyte cytrynową kitajką starą łataną”) i ,ornat fioletowy jednostajny z herbem Pacowskim z[e] stułą i manipularzem podszyty pół tabinkiem fioletowym stary (w 1724 r. dopowiedziano, że był ,blaszkowy z kwiatami złotemi i fioletowemi kolumną tejże materii [...] z galonami złotemi, frędzlą złotą")" (LMAVB f. 43-19583, k. 6-7v, $20 \mathrm{v}, 22)$. Paramenty te nie zachowały się.

76 Zob. przypis 66.

77 Skarbiec..., s. 164. Puszka znajduje się w Bažnytinio paveldo muziejus w Wilnie (nr inw. VA-102, wysokość 23,8 , średnica stopy $9,5 \mathrm{~cm}$ ).

78 Puszka została odnotowana w inwentarzu katedry z 1712 r. Opisano ją wówczas jako „szczerozłota z nakrywką bez krzyża na wierzchu J[ego]m[o]ści x[ę]dza Paca biskupa wileńskiego”. LMAVB f. $43-19583$, k. 2.

${ }^{79}$ Skarbiec..., s. 164. Zob. także Świat ze srebra. Złotnictwo augsburskie od XVI do XIX wieku w zbiorach polskich, red. A. Fryz-Więcek, Kraków 2005, s. 74-76; M.F. Woźniak, Złotnictwo sakralne Prus Królewskich. Studium typologiczno-morfologiczne, Toruń 2012, cz. 1, s. 68-71, 108-109; cz. 2, s. 33-35, 80-81. W XVIII w. kielichy tego typu były wykonywane w różnorodnych warsztatach całej Rzeczpospolitej.

${ }^{80}$ Tak określono ją w inwentarzu katedralnym z 1698 r. LMAVB f. 43-228 (Acta venerabilis capituli Vilnensis..., XVII w.), k. 3v. 
przy tym zamontowanych. Choć wprowadzając je inspirowano się rozwiązaniami południowoniemieckimi, w tym warsztatami augsburskimi, ostateczny efekt należy uznać za wyjątkowo nieudany ${ }^{81}$. Dla daru Mikołaja Stefana Paca nie odnaleziono bliższych analogii, co ma najpewniej związek z pozostawianiem gładko ukształtowanych kielichów/puszek z zasady nieozdabianych aplikacjami czy też kameryzowaniem. Niemniej zdarzały się precedensy dekorowania takich kielichów dekoracją repusowaną (np. kielich z kościoła w Jaksicach Piotra II Rodego, 1676-1689), która, podobnie jak plakietki na omawianej puszce, psuła ostateczny efekt ${ }^{82}$. Plakietki wykonane w technice emalii malarskiej zostały na wileńskim zabytku wprowadzone na wyraźne życzenie dysponenta, pragnącego zaznaczyć przez indywidualny program swoją osobę.

Dotychczas puszkę datowano na lata 1671-1684. Pomocne w doprecyzowaniu czasu jej wykonania będzie przypomnienie o perturbacjach nominata $\mathrm{z}$ kapitułą oraz oprawa sześciopolowego herbu Mikołaja Stefana Paca, która stanowi fuzję omówionych wyżej kompozycji miedziorytniczych z 1682 roku. Tak jak w obu grafikach, tak i na plakietce w górną część tarczy herbowej wpisano hierogram Maryi. Tarczę zwieńczono kapeluszem biskupim $\mathrm{z}$ chwostami (analogie do Modus et ordo boni), a ujęto pastorałem i mieczem (Honor consummatus liliorum). Po bokach kompozycji heraldycznej znajdują się litery „N S P / D G / E V". Obecność w herbie Mikołaja Stefana Paca pastorału i miecza pozwalają na ostateczne doprecyzowanie datowania vasa sacra na lata 1682-1684, czyli na czas po konsekracji i moment oficjalnego wygaszenia konfliktu pomiędzy Mikołajem Stefanem Pacem a kapitułą wileńską ${ }^{83}$.

Program ideowy puszki oparto na zaakcentowaniu godności poprzez genealogię i sprawowaną władzę z odwołaniem do patronów biskupa - Maryi i św. Mikołaja. Obecność św. Kazimierza usprawiedliwiało jego opiekuństwo nad katedrą i diecezją, a także Wielkim Księstwem Litewskim. Zdarzało się, że świętego królewicza łączono z Gozdawitą na tronie biskupim, bowiem ,lilia nie tylko w ręku ś[w]. Kazimierza (którego depozytu stróż Liliat), ale w ręku z nieba od Najświętszej Panny w Surianie przyniesionego Dominika ś[w]. zostająca, tak chwalebnie do Wilna wprowadzona" ${ }^{84}$.

Na koniec warto przypomnieć zapis Mikołaja Stefana Paca z 16 marca 1671 roku na kaplicę Gaudeamus arcybractwa Imienia Maryi ${ }^{85}$, którą wyremontował i ustanowił przy niej

81 Skarbiec..., s. 164.

${ }^{82}$ Dobrze w takich realizacjach spełnia się dekoracja grawerowana, zob. np. puszka z Muzeum Warmii i Mazur w Olsztynie z 1684 r. M. Okulicz, Złotnictwo sakralne dominium warmińskiego od połowy XIV do końca XVIII wieku, Olsztyn 2006, s. 188-189.

83 Warto tu przywołać grafikę z herbem Mikołaja Stefana Paca (część stemmatu) wykonaną po nominacji na biskupstwo wileńskiej lecz przed konsekracją, gdzie z zgodnie z regułami w oprawie

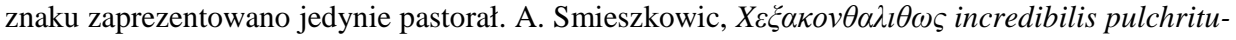
dinis, et incomparabilis percii valorisque, gemma scilicet ecstatica virgo divina Maria Magdalena de Pazzis..., Kraków 1671, k. 1v.

${ }^{84}$ M. Wojniłowicz 1682, k. 3. Przytoczony fragment autorstwa przeora dominikanów w Choroszczy to także aluzja do opieki, jaką Mikołaj Stefan Pac roztaczał nad zakonem. A. S. Czyż, Fundacje..., s. $433-441$.

85 Biorąc pod uwagę dotychczasową wiedzę o sposobach autokreacji przedstawicieli rodu Paców obowiązkowo oznaczających swoje fundacje herbami, należy podtrzymać hipotezę Birute Ruty Vitkauskienè, że księgi wpisów arcybractwa Imienia Maryi (foliant oprawiony w drewniane deski obciągnięte aksamitem z okładziną ze srebrnych plakietek) nie mógł ufundować Mikołaj Stefan Pac. Skarbiec..., s. 160-161. 
probostwo z „należytym dochodem”86. Czując się jej właściwym fundatorem zapisał do niej „obicie burkatelowe, apparata bogate, srebro, reliquie" ${ }^{87}$. Nie można wykluczyć, że taką proweniencję ma nieodnotowana w aktach kapituły wileńskiej omówiona wyżej puszka. Wydaje się jednak, że do kaplicy tej nie miała trafić niezwykle cenna relikwia św. Marii Magdaleny de'Pazzi jaką tuż po swojej konsekracji Mikołaj Stefan Pac otrzymał od Kosmy III Medyceusza ${ }^{88}$. Jak udowodnił włoski badacz Giovanni Matteo Guidetti kosztowny (m.in. kryształ górski, złoto, diamenty, emalia) i misterny relikwiarz w typie ostensorium wykonali w 1682 roku florenccy mistrzowie Giovanni Comparini i Giuseppe Vanni ${ }^{89}$. Mikołaj Stefan Pac umieścił dar od Medyceusza w pałacu biskupim w Wilnie. Po jego śmierci, kiedy kanonicy spisywali znajdujący się przy nim majątek oddali relikwiarz kustoszowi skarbca katedralnego ${ }^{90}$. W związku z tym, że św. Maria Magdalena de’Pazzi była karmelitanką bosą, a w wileńskim kościele tego zgromadzenia i jednocześnie mauzoleum rodu biskup chciał być pochowany i tam przekazywał wszelkie swoje „,apparata" ${ }^{91}$, można śmiało założyć, że wśród nich znaleźć się miał się także dar Kosmy III Medyceusza ${ }^{92}$.

${ }^{86}$ K. Niesiecki, op. cit., s. 230. Do arcybractwa maryjnego Mikołaj Stefan Pac powrócił w testamencie: „fundowałem przy kościele katedralnym wileń[skim] bractwo Imienia Najśw[iętszej] Panny, gdzie także co dzień za duszę moją msza ś[więta] powinna się odprawować” (LDM B-5 Ap-1 b-15, k. 4v), co stanowi nieco przesadne podkreślenie jego zasług dla powstania tego religijnego stowarzyszenia. Niemniej zapisując 16 III 1671 r. niebagatelną sumę 20 tysięcy złotych na utrzymanie stałego nabożeństwa był jej głównym dobrodziejem. Zob. także LDM B-5 Ap-1 b-15, k. 4-4v; LVIA SA 26 (Dokument kapituły wileńskiej, Wilno 11 VI 1684 r.), k. 123-124; W. Zahorski, op. cit., s. 116-117; J. Kurczewski, op. cit., t. 3, s. 198.

${ }^{87}$ LDM B-5 Ap-1 b-15, k. 7.

88 ASF MP 4494 (List Kosmy III do Mikołaja Stefana Paca, Florencja 29 VIII 1682 r.), k. 731-731v. Był to rewanż za pozyskanie relikwii św. Kazimierza, o co Medyceusz zabiegał bezpośrednio u Mikołaja Stefana Paca co najmniej od początku 1676 r. Relikwie św. Marii Magdaleny de'Pazzi były bardzo rzadko wydzielane co oczywiście podnosiło ich wartość. W XVII w. posiadali je najbardziej prominentni przedstawiciele elit Kościelnych i udzielni władcy na terenie Półwyspu Apenińskiego. W Rzeczpospolitej relikwie karmelitanki posiadał jedynie brat biskupa wileńskiego Krzysztof Zygmunt, który umieścił je w kościele Kamedułów w Pożajściu. Zob. A.S. Czyż, Fundacje..., s. 363.

${ }^{89}$ Relikwiarz (wys. $13 \mathrm{~cm}$ ) znajduje się w Bažnytinio paveldo muziejus w Wilnie (nr inw. VA-135). K. Niesiecki, op. cit., s. 219; Skarbiec..., s. 41, 65, 162; G. M. Guidetti, Il reliquairio di santa Maria Maddalena de'Pazzi a Vilnius e l'attività di Giovanni Comparini e Giuseppe Vanni per la corte di Toscana: nuovi documenti, „Bollettino della Accademia degli Euteleti della Città di San Miniato”, 2012, nr 79, s. 197-200 (tu błędna informacja, że relikwiarz znalazł się w Pożajściu, a dopiero po śmierci biskupa został przekazany do skarbca katedry w Wilnie).

${ }^{90}$ LMAVB f. 43-19583, k. 2; Summaryjny..., s. 107; W. Przyagłowski, op. cit., t. 3, s. 63-64; J. Kurczewski, op. cit., t. 3, s. 251.

${ }^{91}$ Mikołaj Stefan Pac pisał w testamencie: „Apparata moje wszytkie zapisuję tam (które przy mnie są), gdzie będę leżał tj. do kościoła oo. karmelitów bosych wileńskich”. LDM B-5 Ap-1 b-15, k. 7-7v. Zob. także LDM B-5 Ap-1 b-15, k. 5v.

${ }^{92}$ LDM B-5 Ap-1 b-15, k. 6v. 


\section{ZAKOŃCZENIE}

Choć Mikołaja Stefana Paca nie można uznać za pierwszorzędnego dobrodzieja skarbca katedralnego to jednak należy on do barwniejszych postaci zasiadających na tronie biskupstwa wileńskiego. Perturbacje związane z zatwierdzaniem na urzędzie połączone z kłótliwą naturą i zbyt wielką pewnością siebie, a przy tym, jak się wydaje, niezbyt wyrafinowany gust hierarchy sprawiły, że nie może poszczycić się fundacjami artystycznymi na miarę dzierżonej godności. Mikołajowi Stefanowi Pacowi nie można jednak odmówić historycznej wrażliwości, którą umiejętnie wplatał we własną autokreację, a także zwykłej dbałości o przedmioty, które zostały powierzone jego pieczy.

\section{LITERATURA}

1. Bobiatyński K., Michat Kazimierz Pac-wojewoda wileński, hetman wielki litewski. Dziatalność polityczno-wojskowa, Warszawa 2008.

2. Bogacka K., Insygnia biskupie w Polsce. Pierścień, pektorat, infuła XI-XVIII w., Warszawa 2008.

3. Bonito Fanelli R., Five Centuries of Italian Textiles. 1300-1800. A Selection from the Museo del Tessuto Prato, Firenze 1981.

4. Borkowska M., Leksykon zakonnic polskich epoki przedrozbiorowej, t. 2 i 3, Warszawa 2005 i 2008.

5. Czarski B., Stemmaty w staropolskich ksiązkach, czyli rzecz o poezji heraldycznej, Warszawa 2012.

6. Czyż A.S., Fundacje artystyczne rodziny Paców: Stefana, Krzysztofa Zygmunta i Mikołaja Stefana. „Lilium bonae spei ab antiquitate consecratum”, Warszawa 2016.

7. Czyż A.S., Kościót świętych Piotra i Pawta na Antokolu w Wilnie, Wrocław-Warszawa-Kraków 2008.

8. Czyż A.S., Pacowska pompa funebris - pamięć o zmartych jako element propagandy rodu [w:] Nie wszystek umrę. Pamięć o zmartych $w$ kulturze staropolskiej, red. Jankowski A., Klonder A., Bydgoszcz 2015, s. 93-111.

9. Davanzo Poli D., Riccadona N.M., Panteghini I., Masiero E., Majcen M., Otto secoli di arte tessile ai frari: sciamiti, velluti, damaschi, broccati, ricami, Padova 2014.

10. Diariusz sejmu nadzwyczajnego 1670 roku, oprac. Przyboś K., Ferenc M., Kraków 2004.

11. Drews J., Honor consummatus liliorum [...] Nicolai Stephani Pac [...] episcopi Vilnensis..., Wilno 1682.

12. Gryglewski P., De sacra antiquitate. Odwołanie do przeszłości w polskiej architekturze sakralnej XVI wieku, Warszawa 2012.

13. Guidetti G.M., Il reliquairio di santa Maria Maddalena de'Pazzi a Vilnius e l'attività di Giovanni Comparini e Giuseppe Vanni per la corte di Toscana: nuovi documenti, „Bollettino della Accademia degli Euteleti della Città di San Miniato”, 2012, nr 79, s. 197-215.

14. Jamski P., Ottarz relikwiarzowy w wileńskiej kaplicy św. Kazimierza w pierwszej połowie XVII wieku, „Barok. Historia-Literatura-Sztuka” 12, 2005, nr 2, s. s. 41-44.

15. Janicki M., Willa Eustachego Wołtowicza w Werkach pod Wilnem i jej epigraficzny program ideowy, „Barok. Historia-Literatura-Sztuka”, 6, 1997, nr 2, s. 123-149.

16. Kałamajska-Saeed M., Litewska Pietà Michała Anioła [w:] Mowa i moc obrazów. Prace dedykowane profesor Marii Poprzęckiej, Warszawa 2005, s. 55-58. 
17. Kobielus S., Bestiarium chrześcijańskie. Zwierzęta w symbolice i interpretacji. Starożytność i średniowiecze, Warszawa 2002.

18. Kraszewski J.I., Wilno od początków jego do roku 1750, t. 2, Wilno 1840.

19. Kurczewski J., Kościót zamkowy czyli katedra wileńska w jej dziejowym, liturgicznym, architektonicznym i ekonomicznym rozwoju, t. 1, Wilno 1908; t. 3, Wilno 1916.

20. Lengnich G., Prawo pospolite Królestwa Polskiego, Kraków 1836.

21. Lietuvos didžiosios kunigaikštystès valdu ir didiku portretami iš ukrainos muziejų [katalog wystawy], Lietuvos dailès muziejus Vilniaus paveikslų galerija, 4 VII - 28 X 2012, Vilnius 2012.

22. Lietuvos sakralinè dailè XI-XX a. pradžia. Lietuvos tūkstantmečio programos ir Jubilejiniu 2000 metu parodos krikščionybe Lietuvos mene katalogas [katalog wystawy], Lietuvos dailès muziejus, t. 4 kn. 1, Vilnius 2006.

23. Liškevičienè J., Mundus emblematum: XVII a. Vilniaus spaudiniu ilustracijos, Vilnius 2005.

24. Matušakaitė M., Portretas lietuvos didžiojoje kunigaikštystëje, Vilnius 2010.

25. Modus et ordo boni regiminis in dioecesim Vilnensem introducendi sancitus et ex mandato [...] Nicolai Stephani Pac..., Vilnae 1682.

26. Niesiecki K., Herbarz Polski, wyd. J.N. Bobrowicz, t. 7, Lipsk 1841.

27. Okulicz M., Złotnictwo sakralne dominium warmińskiego od połowy XIV do końca XVIII wieku, Olsztyn 2006.

28. Pauliukevičiūtė R., Šilkas ir auksas. XV-XVIII a. šilkiniai audiniai Bažnytinio paveldo muziejaus liturginiu drabužiu rinkinyje, Vilnius 2014.

29. Pesci L., Il manifatture fiorentine del cinque e seicento nella collegiata di Montevarchi, „Jaquard”, 2001-2002, nr 48, s. 2-6, 13.

30. Przyagłowski W., Żywoty biskupów wileńskich, t. 3, Petersburg 1860.

31. Rachuba A., Pac Mikołaj Stefan [w:] PSB, t. 24, Wrocław-Warszawa-Kraków-Gdańsk 1979, s. 738-741.

32. Sapieha M.J., Lilium praesulea tiara coronatum [...] in solenni inauguratione in antistitem Vilnensem [...] Nicolai Stephani Pac..., Varsavia 1682.

33. Smieszkowic A., X $\varepsilon \alpha \kappa o v \theta \alpha \lambda \imath \theta \omega \varsigma$ incredibilis pulchritudinis, et incomparabilis percii valorisque, gemma scilicet ecstatica virgo divina Maria Magdalena de Pazzis..., Kraków 1671.

34. Stróżyk P., O potrzebie i możliwościach badań nad herbami złożonymi. Uwagi na przykładzie ikonograficznych źródet heraldycznych z Wielkopolski [w:] Ad fonts. O naturze źródta historycznego, red. Rosik S., Wiszewski P., Wrocław 2004, s. 201-225.

35. Summaryjny wypis z protokołów aktów kapituty kathedralnej wileńskiej od r. 1501 do r. 1783 października 22, oprac. Bohusz K. [w:] Описаніе рукописнаго отдъленія Виленской публичной библіотеки..., вып. 1, Вильна 1895.

36. Świat ze srebra. Złotnictwo augsburskie od XVI do XIX wieku w zbiorach polskich, red. Fryz-Więcek A., Kraków 2005.

37. Taszycka M., Wtoskie jedwabne tkaniny odzieżowe w Polsce w pierwszej połowie XVII wieku, Wrocław-Warszawa-Kraków-Gdańsk 1971.

38. Topolska M.B., Społeczeństwo i kultura w Wielkim Księstwie Litewskim od XV do XVIII wieku, Poznań-Zielona Góra 2002.

39. Tylkowski W., Disquisitio physica ostenti duorum puerorum..., Oliva 1674.

40. Vitkauskienė B.R., Złotnictwo wileńskie. Ludzie i dzieła XV-XVIII wieku, Warszawa 2006. 
41. Wijuk Kojałowicz K., Kazania o męce Pańskiej [...] w kościele wileńskim ś[w]. Jana [...] na wielki piątek miane..., Wilno 1675.

42. Wojniłowicz M., Exultavit [...] Mikołajowi Stefanowi Pacowi [...] przy solennym dziękczynieniu Panu Bogu za otrzymana w Rzymie expedycyia..., Wilno 1682.

43. Wolff J., Pacowie. Materyjały historyczno-genealogiczne, Petersburg 1885.

44. Woźniak M.F., Złotnictwo sakralne Prus Królewskich. Studium typologiczno-morfologiczne, Toruń 2012.

45. Zahorski W., Katedra wileńska, Wilno 1904.

46. Zujienė G., Ceremoniat ingresu biskupów wileńskich w XVII-XVIII wieku, „Barok. HistoriaLiteratura-Sztuka", 13, 2006, nr 1, s. 59-77.

47. Zujienė G., Historia skarbca katedry wileńskiej (od założenia do dzisiaj) [w:] Skarbiec katedry wileńskiej. Zamek Królewski w Warszawie 2 lipca - 28 września 2008, Zamek Królewski na Wawelu 15 października 2008 - 15 stycznia 2009 [katalog wystawy], red. Nowacki D., Saratowicz-Dudyńska A., Warszawa 2008, s. 31-49.

\section{ARCHIWA}

1. AGAD AR dz. II.

2. AGAD AR dz. V nr 11214/2.

3. AGAD Platerowie z Antuzowa, nr 8.

4. Archiwum Narodowe w Krakowie oddz. Wawel ZZG 754.

5. ASF MP 4493.

6. ASF MP 4494.

7. BCzart 425.

8. LDM B-5 Ap-1 b-15.

9. LMAVB f. 43-228.

10. LMAVB f. 43-19583.

11. LMAVB f. 264-1362.

12. LMAVB f. $273-2425$.

13. LMAVB f. 318-2309.

14. LVIA SA 7.

15. LVIA SA 9.

16. LVIA SA 25.

17. LVIA SA 26.

18. LVIA f. 694 ap 1 no 3670.

19. VUB f. 3-2109.

20. VUB f. 3-2237.

21. VUB f. 4-A 2472.

22. VUB f. 32295. 


\section{MEMORIES OF PREDECESSORS AND DISPUTES WITH THE CHAPTER, OR THE ACTIVITY OF BISHOP MIKALOJUS STEPONAS PACAS ON BEHALF OF THE TREASURY IN VILNIUS CATHEDRAL}

The article focuses on a relatively little known aspect of the history of the cathedral in Vilnius and its treasury, during the period from 1671 until 1684, when Mikalojus Steponas Pacas was Bishop. His episcopate was difficult as it was the period of disputes with a chapter reluctant to nominate him, his struggle for the episcopal see with Kazimieras Pacas, his relative and Bishop of Samogitia, and of rebuilding Vilnius and the Grand Duchy of Lithuania after the period of wars and the occupation by Muscovy.

While strengthening his position, Mikalojus Steponas Pacas referred to his great predecessors, thus creating a sort of spiritual genealogy linked with the history of the state and the diocese. He cherished the memory of the bishops of Vilnius by caring for the objects from the treasury in the cathedral, their liturgical foundations, and the various prints and accompanying graphics. His well thought-out self-creation was connected with the need for sacral legitimisation.

Mikalojus Steponas Pacas's contribution in equipping the cathedral's treasury is presented against this backdrop. A critical analysis of previous opinions concerning his outstanding input to the history of the cathedral's treasury and its interesting artistic foundations has been made.

Keywords: Mikołaj Stefan Pac/Mikalojus Steponas Pacas, Diocese of Vilnius, the Pac family, Vilnius/Wilno, Grand Duchy of Lithuania, artistic foundations.

DOI: $10.7862 /$ rz.2018.hss.36

Przestano do redakcji: kwiecień $2018 r$.

Przyjęto do druku: wrzesień 2018 r. 